\title{
Validation of Managers Strategic Thinking Mindset Test based on components of intellectual flexibility, intellectual humility, and intellectual inclusiveness
}

\author{
Meysam Sadeghi' ${ }^{1}$ Hossein Hassanpoor ${ }^{2 *}$ iD \\ 1. Assistant Professor of Psychometrics, Department of Cognitive Psychology, Institute for Cognitive Science Studies, Tehran, Iran \\ 2. Assistant Professor of Medical Engineering, Ati Negar Cognitive Data Processing Institute, Department of Cognitive Sciences, Tehran, Iran
}

Recieved: 15 Feb. 2020

Revised: 21 Apr. 2020

Accepted: 23 May. 2020

\section{Keywords}

Situational judgment test Strategic thinking Intellectual flexibility Intellectual humility Intellectual inclusiveness

Corresponding author Hossein Hassanpoor, Assistant Professor of Medical Engineering, Ati Negar Cognitive Data Processing Institute, Department of Cognitive Sciences, Tehran, Iran

Email: H.hassanpoor@hotmail.com

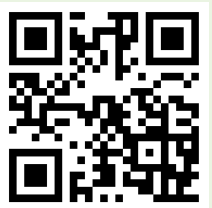

doi.org/10.30699/icss.22.2.22

\section{Abstract}

Introduction: The Persian versions of the Strategic Thinking Scales in the country are all self-reporting. It is also not suitable for military organizations. The present study aimed to investigate the validity and reliability, as well as to extract the normative scores of the Military Managers' Strategic Thinking Test (STMT) based on situational judgment and the components of intellectual inclusiveness, intellectual humility, and intellectual flexibility.

Methods: The statistical population in this study included all managers and staff of the National Defense University in the first half of 2019, of which 189 people were evaluated. The Military Managers Strategic Thinking Test was designed by Weyhrauch (2017) and under the auspices of the US Army Institute for Military Studies in Behavioral and Cognitive Sciences. The test consists of 12 scenarios in which the respondent chooses one answer in each scenario. The Goldman Strategic Thinking Questionnaire (2007) was also used to assess criterion validity.

Results: Analysis of research data showed that the structure based on three subscales using the confirmatory factor analysis to explain and fit a good situation. Also, the reliability coefficients of internal consistency and test-retest were optimal. Accordingly, the researcher's hypothesis that the structure is based on three components of intellectual inclusiveness, intellectual humility, and intellectual flexibility is confirmed.

Conclusion: It seems that research evidence supports the consideration of all three components as cognitive dimensions for strategic military thinking, and this test can be used in military assessments.

Citation: Sadeghi M, Hassanpoor H. Validation of Managers Strategic Thinking Mindset Test based on components of intellectual flexibility, intellectual humility, and intellectual inclusiveness. 2020;22(2):22-32. 


\title{
اعتباريابى آزمون تفكر راهبر دى مديران بر اساس مؤلفههاى جامعيت فكرى، تواضع فكرى وانعطافيذيرى شناختى
}

\author{
ميثم صادقى'، حسين حسن ثيور

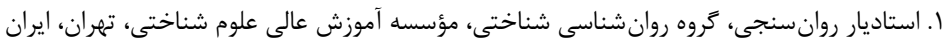

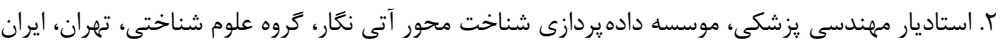

\section{ars}

مقدمه: نسخه هاى فارسى مقياس هاى سنجش تفكر راهبردى در كشور همكى بر اساس خوداظهارى هستند. همجنين مناسب با سازمان هاى نظامى نيستند. هدف يزوهش حاضر بررسى روايى و پايايى و استخراج نمرات هنجار آزمون تفكر استراتريك مديران نظامى مبتنى بر قضاوت موقعيتى و بر اساس مؤلفه هاى جامعيت فكرى، تواضع فكرى و انعطاف يذيرى شناختى بود. روش كار: جامعه آمارى بروهش حاضر شامل همه مديران و كاركنان دانشخاه عالى دفاع ملى در نيمه اول سال ^وسا بود. كه از بين آنها تعداد 119 نفر به عنوان نمونه مورد بررسى قرار كرفتند. شركت كنندكان با استفاده از آزمون تفكر رك استراتزيك مديران نظامى توسط Weyhrauch (Y. V) كه تحتنظر مؤسسه مطالعات نظامى مرتبط با علوم رفتارى و شناختى ارتش آمريكا طراحى شده است مورد ارزيابى قرار كَرفتند. اين آزمون شامل rا سناريو است كه پاسخ گو در هر

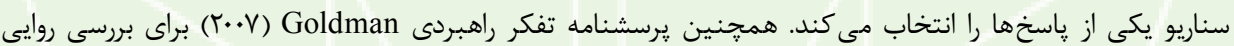
ملاكى به كار ترفته شد. يافته ها: تحليل دادههاى بروهش نشان داد ساختار مبتنى بر ب خرده مقياس با استفاده از تحليل عاملى تاييدى جهت تبيين و برازش از وضعيت مناسبى برخوردار است. همجنين ضرايب پايايى همسانى درونى و بازآزمايى در حد مطلوب بود. بر اين اساس مفروضه يروهشكر مبنى بر ساختار مبتنى بر r مؤلفه جامعيت فكرى، تواضع فكرى و انعطاف يذيرى شناختى مورد تأييد قرار كرفت نتيجه گَيرى: با توجه به نتايج يزوهش به نظر مىرسد شواهد يُوهشى از در نظر گرفتن هر سه مؤلفه تحت عنوان ابعاد شناختى براى تفكر راهبردى نظامى، حمايت مى كند و مى توان اين آزمون را در ارزيابى هاى نظامى مورد استفاده قرار داد.

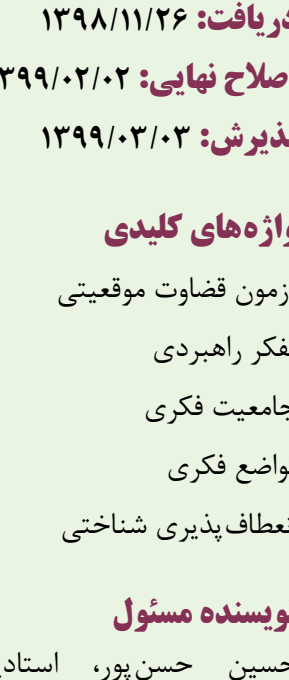

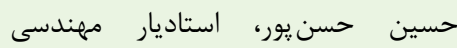
يزشكى، موسسه داده يردازى شناخت محور آتى نغار، كروه علوم شناختى، تهران، ايران

ايميل: H.hassanpoor@hotmail.com

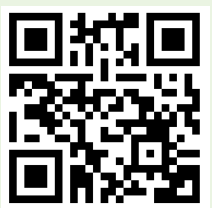

dol doi.org/10.30699/icss.22.2.22

مقدمه

》ادهوكراسى" استفاده كرده و تحت فشار جابكى و واكنش سريعتر به محيط، نيازمند توسعه ساختارها و فرآيندها به صورت غيرمتمركزتر و انعطافٍذيرتر هستند (r). شناسايى زمينه (باى محيطى سازمان در جهت تعيين جَُّنَى برناملريزى مناسب استراتزيكى از اهميت بالايى برخوردار است. محيطهايى با روندهاى مداوم و تغييرات ساختارى

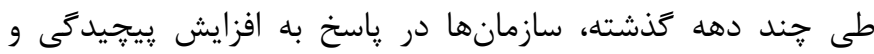
غيرقابل يِيشبينى بودن محيط، به تحول ساختارها و فرآيندهاى خود يرداختهاند (1). در گذشته ساختارهاى سازمانى بسيار بوروكراتيك يك بوده است و با سطوح سلسلهمراتبى معين و تقسيمات وظيفهاى مشخص مىشدند. در مقابل، امروزه بسيارى از سازمانها از ساختار 
ليستى مشابه در ادبيات يزوهشى در حوزه مديريت، شامل توانايى شناختى، شخصيت و تجربه كارى است ( • (1). به طور كلى، ذهنيت تفكر استراتزيك بيانگر تمايل فرد براى حل مسائل به شكلى است كه با عناصر تفكر استراتزيك سازگًار باشد، به ويزه از نظر

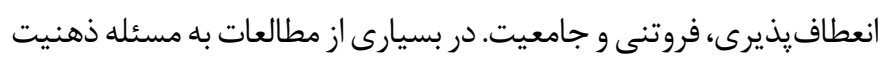
تفكر استراتزيك يرداخته شده است (ها، ع|). داشتن ذهنيت تفكر استراتزيك در كنار توانايى شناختى و دانش گسترده براى تبديل شدن به يك متفكر استراتزيك موفق، از اهميت بالايى برخوردار است. توانايى ارزيابى اين ذهنيت داراى منافع عملى و نظرى فراوانى براى يزوهشگرانى است كه به تفكر استراتزيك به عنوان يك شايستخى نتاه مى كنند. اين يزوهش به دنبال دستيابى مستقيم به ذهنيت تفكر استراتزيك و از طريق آزمون قضاوت موقعيتى (SJT) (Situational Judgment Test ) است. نخستين ابزارها براى سنجش قضاوت موقعيتى، در اواخر قرن نوزدهم

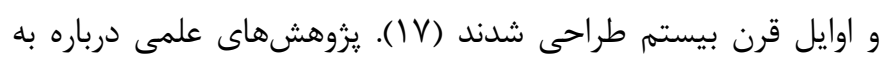
كارگيرى متغيرهاى ييشبينى كننده عملكرد شغلى نشان داد كه يها، ييشبينى كنندههاى نسبتاً قدرتمندى هستند (1) (1). از آن زمان توجه بيشترى به اين ايده معطوف شد كه SJT ها خودشان يك ساختار نيستند، بلكه روش سنجش ساختارها را بيان مى كنند (1) ، 9 (1). از اين رو، توانايى در ييشبينى عملكرد يا هر معيار ديخر، بستخى به ساختارى خواهد

$$
\text { داشت كه براى ارزيابى اين معيار طراحى شده است. }
$$

Pisapia ال تدوين كردند كه (Strategic Thinking Questionnaire) بيان گر نخستين نظريات درباره رهبرى استراتزيك بوده است (ها، •r). در اين يرسشنامه محدوديتهايى از نظر شاخصهاى خود كزارشدهى رفتارى به جشهم مى خورد. به ويزه نتايج به دست آمده با ميانگين بالا و واريانس اندك، حاكى از وجود سوكيرى مطلوبيت اجتماعى از سوى ياسخدهندكان است كه تمايل دارند به شيوهاى كه شرح داده شده رفتار كنند. با استفاده از فرمت SJT، ذهنيت ياسخ دهند كان از طريق انتخابهايى كه با توجه به سناريوهاى و مسائل مختلف انجام مىدهند، تمايلات آنها جهت اتخاذ يك ذهنيت استراتزيك در واكنش به اين مسائل به به و فعاليتهايى كه در اين راستا به انجام مىرسانند، مورد تحليل و استنباط قرار مى گيرد. اين رويكرد اعتبار بالايى را ارائه مى كند جرا كه اينه

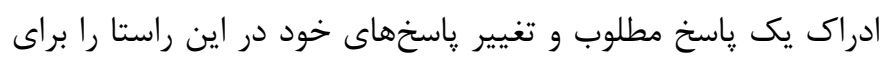
ياسخ دهندكان دشوار خواهد كرد. در عين حال به كمك اين رويكرد مى توان به جاى خود ارزيابى هاى انتزاعى و عمومى، از طريق سناريوهاى مشخص و به صورت مستقيم به ذهنيت مخاطبين دسترسى ييدا كرد.
اندك، نيازمند انتخابهاى استراتزيك متفاوتى از محيطهاى داراى يويايى در جهت گيرى، دامنه و فركانس نيروهاى موجود هستند

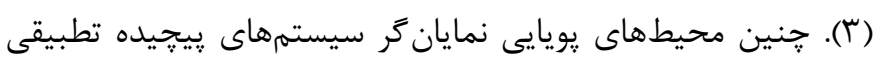
هستند. وقتى سازمان در خنين محيطهايى قرار داشته باشد، اجراى استراترى به منظور اطمينان از عملكرد مناسب به وظيفهاى دشوارتر مبدل شده و نيازمند سرمايهگذارى بيشتر جهت توسعه شايستخى هاى بـى تفكر استراتزيك در سراسر سازمان، به ويزه در ميان رهبران آن خواهد بود. بدين ترتيب، تفكر استراتزيك در كسب و كارهاى مدرن از اهميت

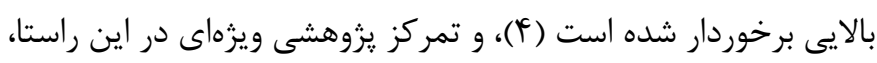
نه تنها به دليل اهميت تفكر استراتزيك در اطمينان از موفقيت سازمانى بلند مدت، بلكه به دليل وجود شواهدى از عدم وجود مهارتهاى تفكر

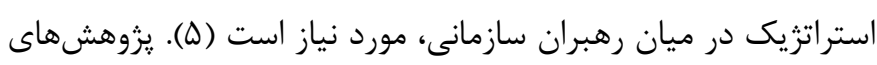
انجام گرفته در زمينه تفكر استراتزيك نه تنها بر مفهومسازى آنجه تفكر ميكر استراتزيك مستلزم آن است متمركز بوده (و، V)، بلكه نحوه توسعه و

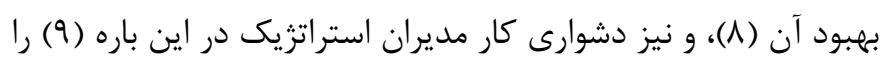

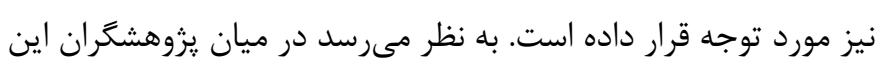
حوزه اجماع مناسبى در زمينه زمان و تجربه مورد نياز براى توسعه تفكر استراتزيك، وجود دارد (• (1). اين روند همجنين توسط يروهشگران حوزه نظامى به عنوان تحول لازم براى نيروهاى مسلح دنبال شد (1). يزوهشكده تحقيقات علوم رفتارى و اجتماعى ارتش ايالات متحده، اخيراً دست به سلسله تحقيقاتى در زمينه بررسى نيازهاى ارتقاى تفكر

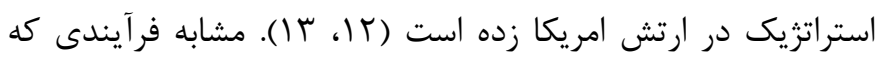
توسط Goldman شرح داده شد، افسران ارتش با توان بالقوه بالا، غالباً با ارتقاى رتبه و تجربيات ناشى از آن، ديدگاه و دانش لازم جهت سطوح استراتزيك فرماندهى را به دست مى آورند (فرماندهى بخش اصول و ونه

آموزش ارتش ايالات متحده). جنانجه به تجربيات خاصى در توسعه تفكر استراتزيك نياز باشد،

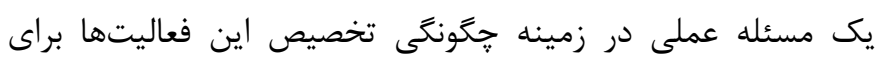

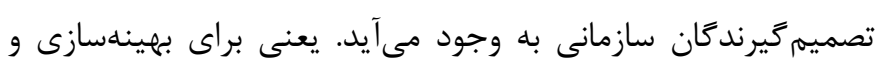

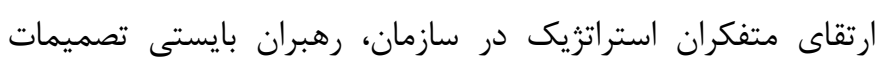

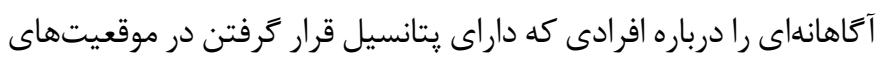
برتر سازمانى هستند اتخاذ كنند، به شيوهاى كه امكان راهنمايى و ارتقاى آنها به صورت صحيح، در جهت استفاده مناسب از مهارتهاى استراتزيك سلر

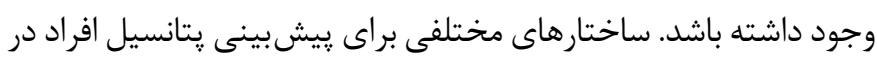

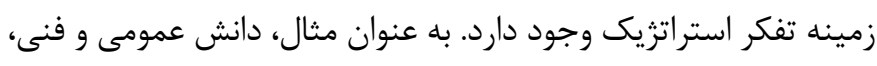

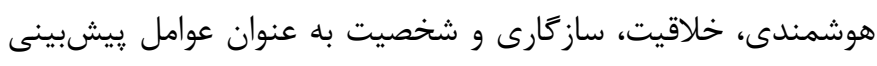
كننده آمادكى شناختى استراتزيك در ارتش شناخته مىشوند (I ( ). 
تمايل به وفق دادن و تطبيق درك، نظر، يا رويكرد فرد زمانى كه شرايط

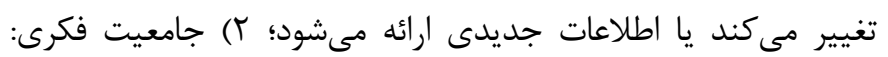

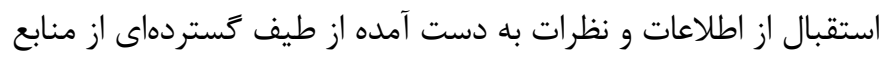

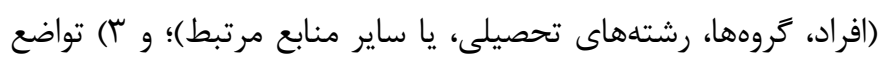

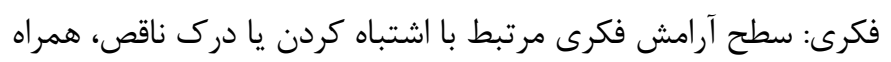

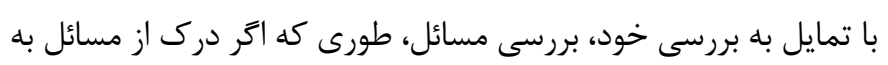

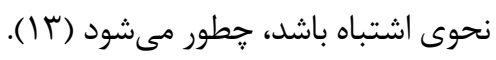

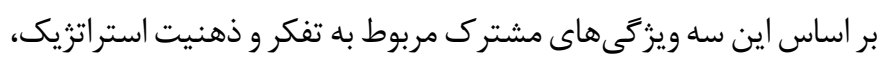

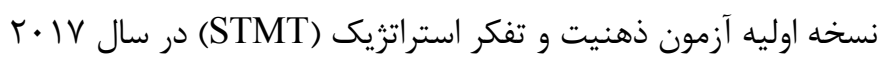

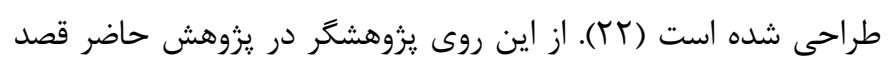

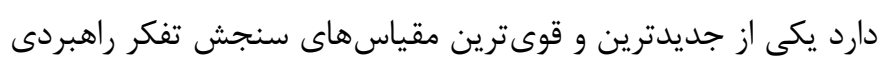

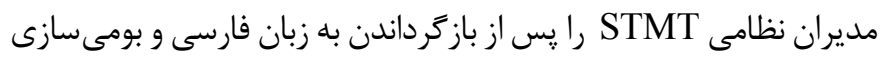

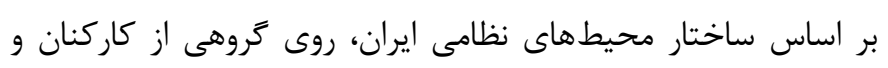

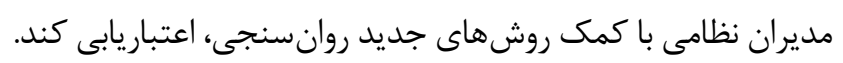

\section{روش كار}

يزوهش حاضر از نظر هدف كاربردى بود. از حيث نوع گَردآورى اطلاعات

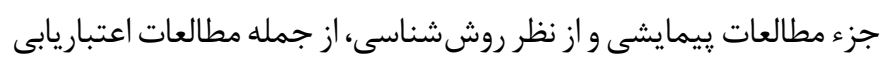

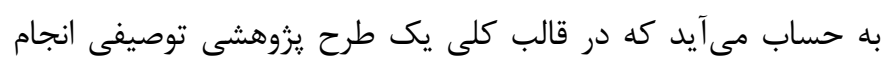

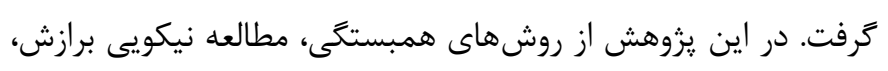

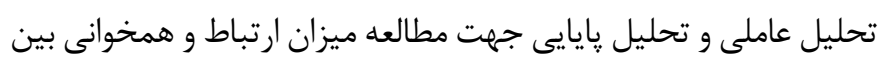

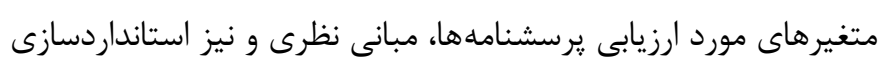

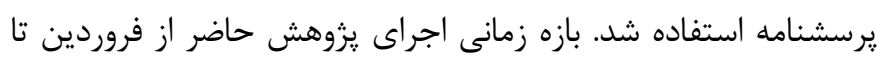

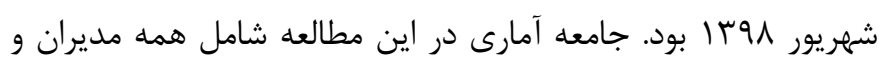

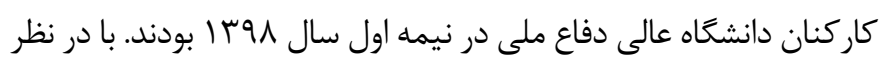

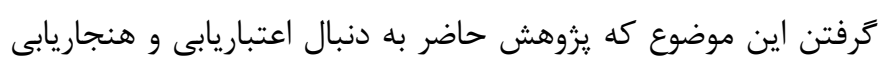

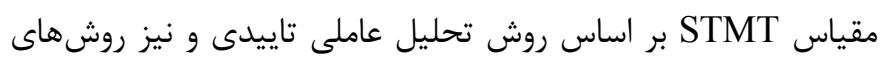

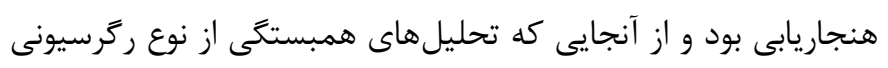

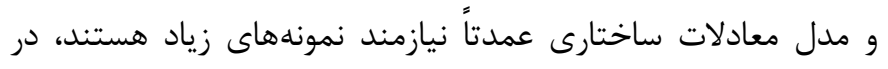

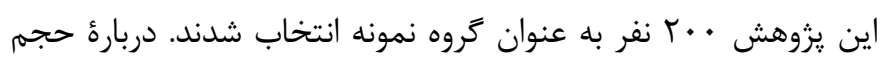

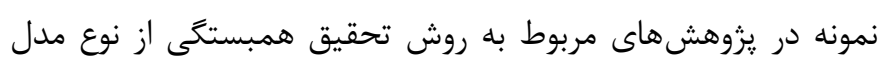

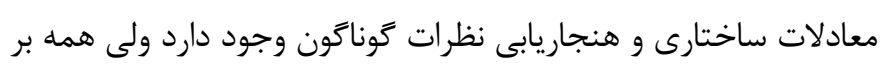

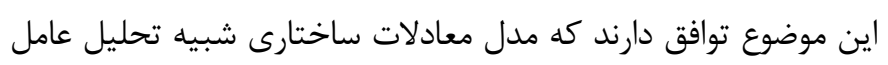

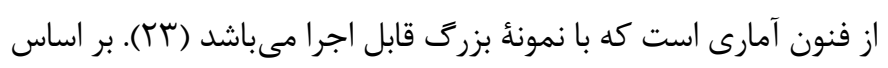

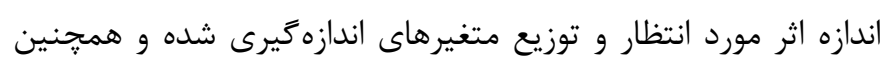

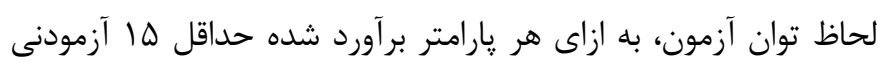

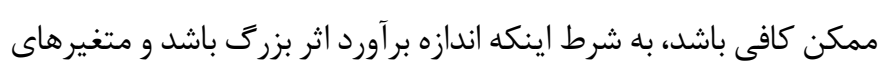

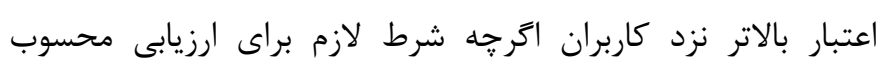

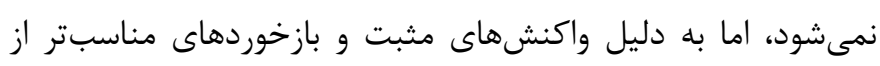

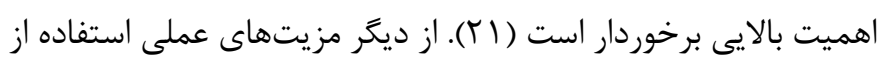

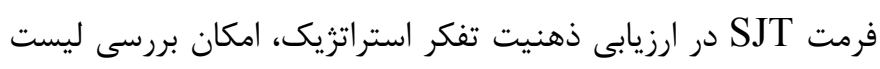

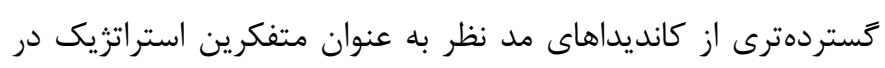

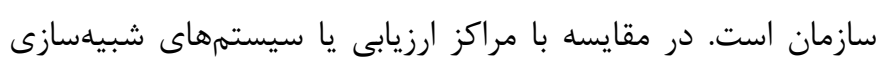

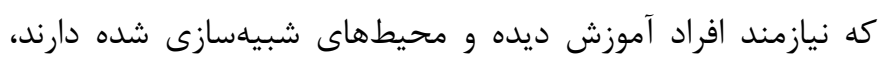

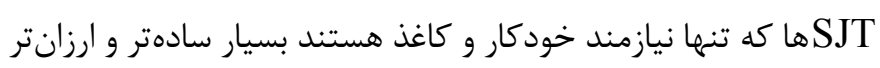

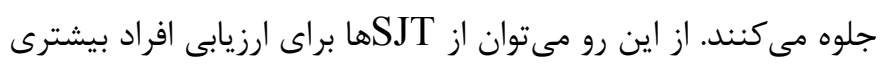

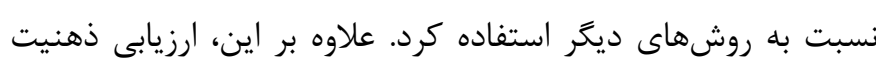

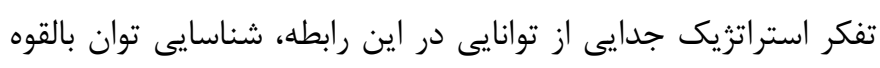

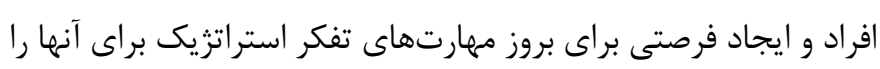
ممكن مى كند. با شناسايى به موقع اين توانايىها، هدايت و توسعه آنها براي به صورت بلندمدت ممكن خواهد شد.

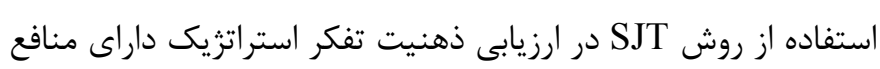

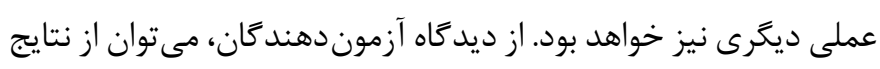

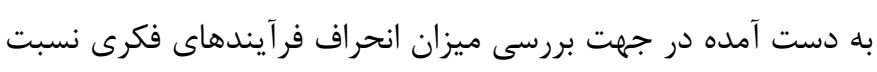

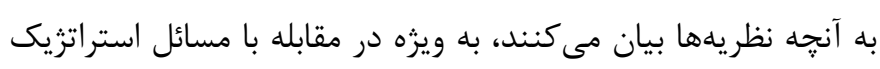

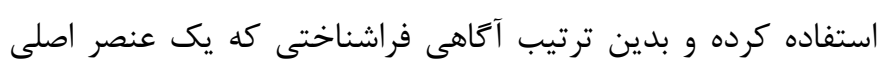

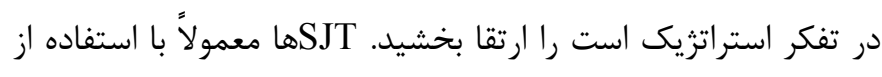
سنار يوهاى مربوط به يك حوزه خاص از عملكرد شغلى ايجاد مى شوند.

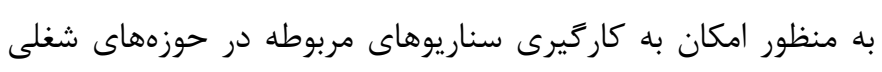

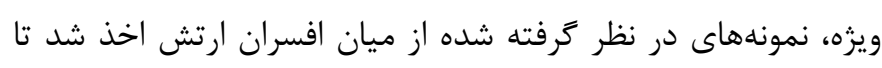

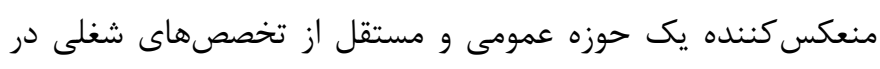

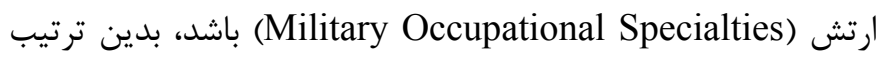
امكان استفاده از اين ابزار ييشرفته در تمامى سازمانهاى نظامى وجود

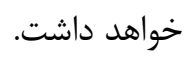
آزمون تفكر استراتزيك مديران نظامى (STMT) (Strategic Thinking

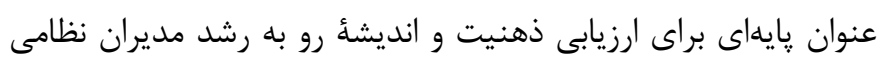

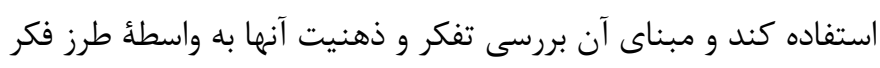

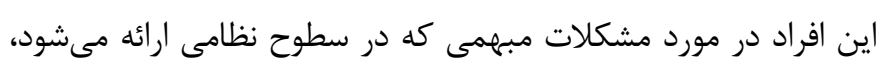

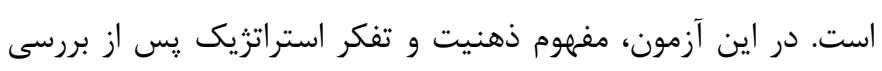

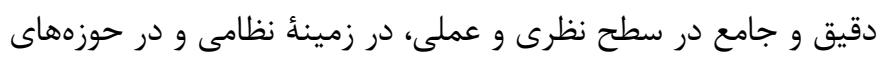

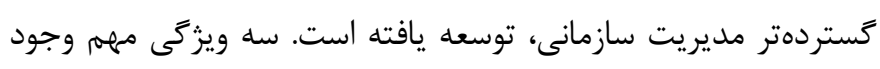

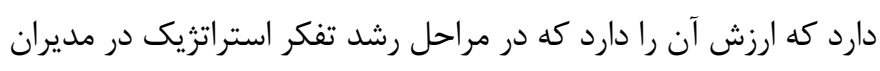

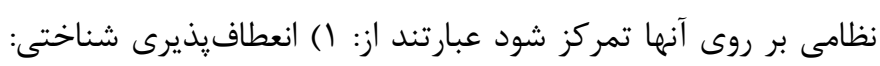


با استفاده از كليد گويه ارائه شده، براى هر گويه امتيازى در نظر گرفته

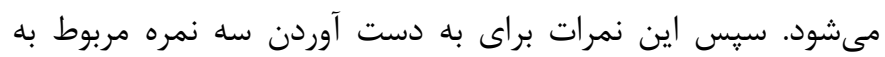

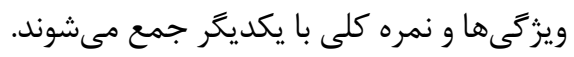

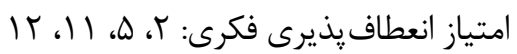

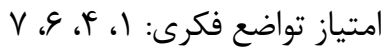

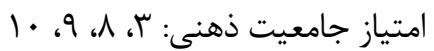
هنخام محاسبة امتيازات، افزودن نمره منفى مانند كم كردن ارزش اصلى الى آن نمره مىباشد. بنابراين، جمع بستن امتيازات ا، ك، · و -r ، همانند (1)

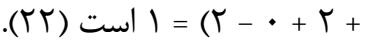

\section{Goldman يرسشنامه تفكر استراتزيك} يرسشنامه تفكر استراتزيك از • ع كويه تشكيل شده است كه به منظور

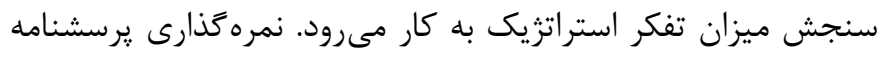

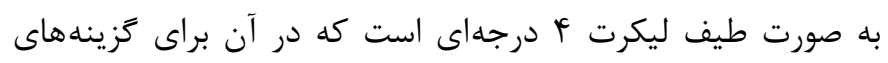

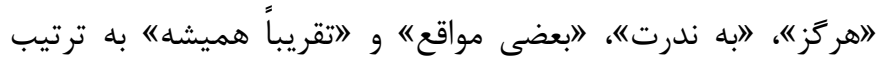

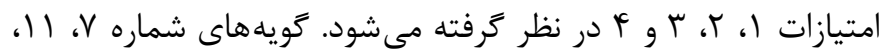

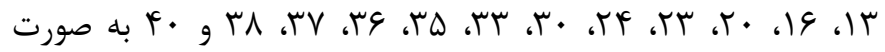
معكوس نمرهگذارى مىشوند. روايى يرسشنامه از دو جنبه محتوا

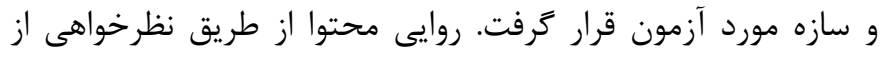
استادان مديريت و روايى سازه با روش تحليل عاملى تاييدى انجام شد.

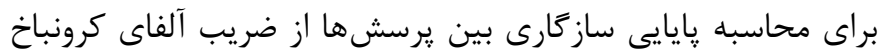
استفاده شد كه بالاى • • • به دست آمد (TF).

\section{يافته ها}

در نخستين كام براى تحليل سؤالات فرم اوليه كا سؤالى ترجمه شده و سيس مجدد نسخه فارسى ترجمه شده به انغليسى بازگردانده شد و مغايرتها مورد بررسى و اصلاح قرار كرفته و نسخه اوليه تدوين شد. به منظور سنجش روايى محتوايى آزمون نظر 1 نفر متخصص ملاك

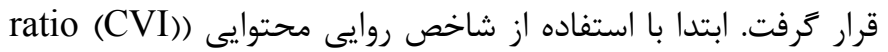
Content validity

\section{$\mathrm{Cvr}=$ ne- $\mathrm{N} / 2 / \mathrm{N} / 2$}

كه در آن ne معادل تعداد افرادى است كه در نظر خواهى آن سوال را به عنوان يك سوال ضرورى مشخص كردهاند و N برابر تعداد كل شركت كنندكان در نظر خواهى است، نمرهاى براى هر سوال به دست مى آيد. سيس هر نمره با شاخصهايى روايى محتوايى كه در

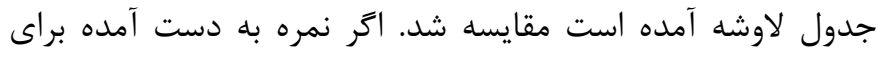

اندازهيرى شده داراى توزيع نرمال باشند (rr). يֶ از اجراى آزمون و

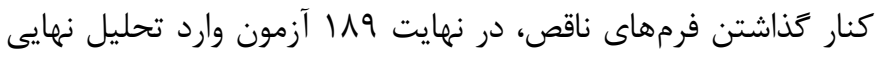

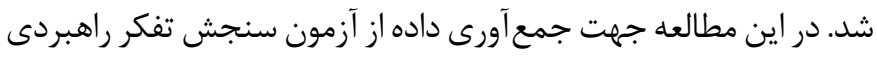
و يرسشنامه تفكر استراتزيك استفاده شد.

\section{آزمون سنجش تفكر راهبردى (STMT)}

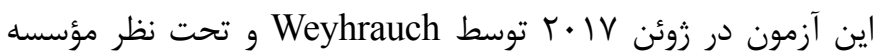
مطالعات نظامى مرتبط با علوم رفتارى و شناختى ارتش آمريكا براساس مؤلفهاى شناختى تفكر راهبردى طراحى و اعتباريابى شد (Tr). اين

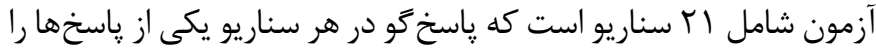
انتخاب خواهد كرد. مبناى اين آزمون مؤلفههاى جامعيت فكرى، تواضع

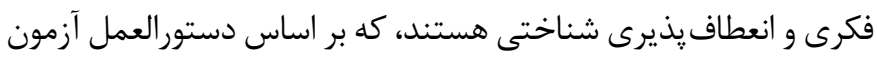

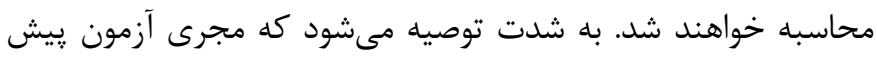

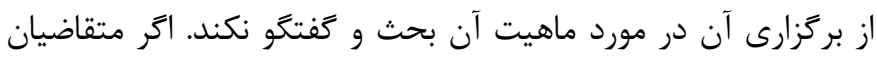

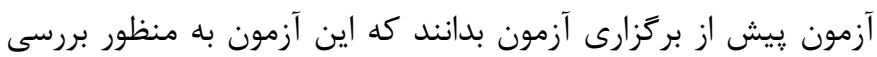

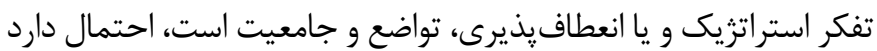
كه ياسخهاى خود را تا حدى تغيير دهند. از آنجايى كه اين آزمون به عنوان تمرينى براى خودآكاهى و بازتابى صادقانه از خود در نظر كرفته شده است، اين دانش ييش از آزمون از ميزان مفيد بودن آزمون مى كاهد.

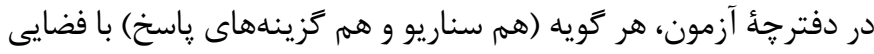
مستطيل شكل خالى براى يادداشتها همراه است. متقاضيان آزمون بايد به نحوى تشويق شوند كه يادداشتهاى خود را بنويسند تا براى هر بران

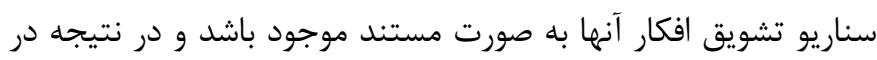
آينده بحث در مورد سناريوها را آسانتر نمايد. نسخه نهايى STMT فقط بر اساس با سناريو است. نتايج تجربى توصيف شده در يزوهش دورد

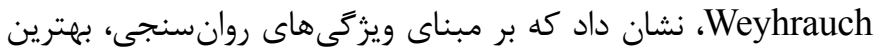
اندازمخيرى از اين سازه با استفاده از كا أمورد به دست مى آيد. مدت زمان

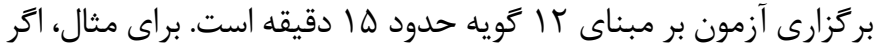

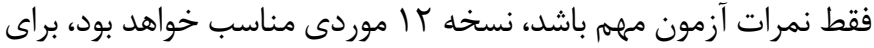

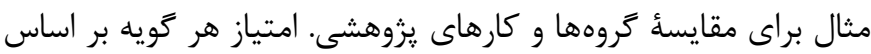
تركيبى از دو پاسخ به دست ميى آيد:

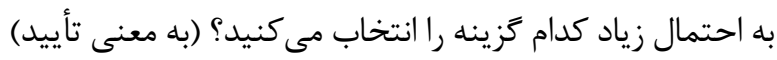

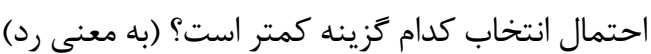

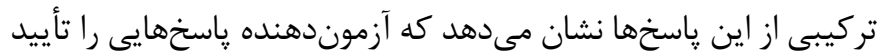
و يا رد مى كند كه ذهنيت و تفكر استراتزيك را درك مى كند يا متوجه نمى شود. اين سيستم براى هر سناريو نمراتى را ارائه مىدهد كه از

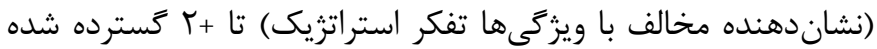
است (همسويى با ويزّكىهاى ذهنى تفكر استراتزيك را نشان مى دهد). 
نسبت براى هر سوال محاسبه شد.

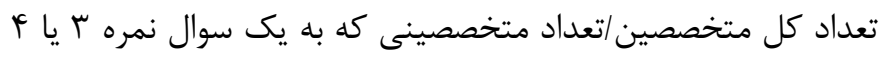

CVI $=$

بر اين اساس سوالاتى كه بالاى VD/ • بود در آزمون نكَه داشته شدند.

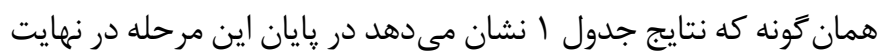

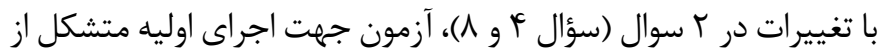
r إسوال كه روايى محتوايى آنها احراز شد آماده گرديد.
هر سوال از نسبت جدول بيشتر باشد آن سوال داراى روايى محتواى

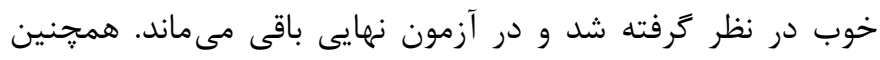

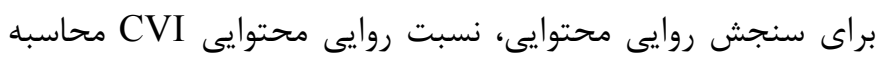

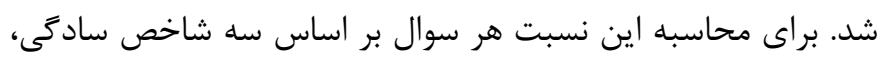

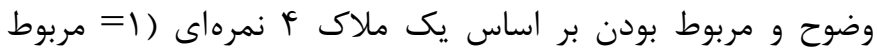

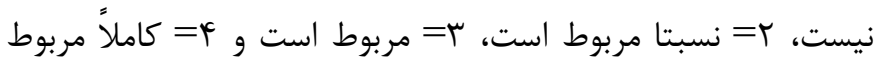
است) توسط متخصصين نمرهخارى شد و بر اساس فرمول زير اين

جدول ا. شاخصهاى روايى محتوايى

\begin{tabular}{|c|c|c|}
\hline CVI & CVR & كويه ها \\
\hline . /AV & $\cdot / V \Delta$ & 1 \\
\hline$\cdot / V \Delta$ & $\cdot / V \Delta$ & $r$ \\
\hline$\cdot \mid A V$ & 1 & $r$ \\
\hline$\cdot / V \Delta$ & $\cdot / V \Delta$ & r \\
\hline$\cdot / A V$ & $\cdot / V \Delta$ & $\Delta$ \\
\hline 1 & 1 & $q$ \\
\hline 1 & $\cdot / V \Delta$ & $v$ \\
\hline$\cdot / V \Delta$ & $\cdot / V \Delta$ & $\Lambda$ \\
\hline 1 & 1 & 9 \\
\hline$\cdot / A V$ & $\cdot / V \Delta$ & 1. \\
\hline$\cdot / A V$ & 1 & 11 \\
\hline - /AV & $\cdot / V \Delta$ & Ir \\
\hline
\end{tabular}

كمترين ضريب تشخيص در آزمون بودهاند. به منظور بررسى روايى سازه فهرست و تاييد ساختار جهار عاملى نسخه فارسى از روش تحليل عاملى تاييدى مرتبه اول و دوم استفاده شد. به عنوان يك گام پيش بين براى تحليل عاملى تاييدى با در نظر ترفتن اين مورد كه متغيرهاى ترتيبى و گويههاى نإييوسته در مدل وجود داشت،

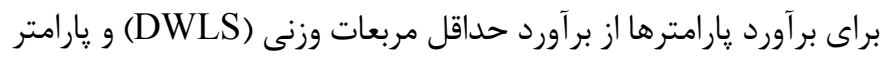
تتا در طول تحليل عاملى تاييدى مرتبه اول و دوم استفاده شد.

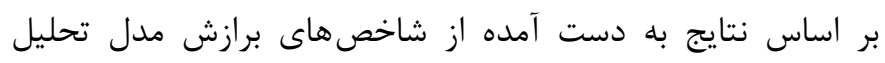

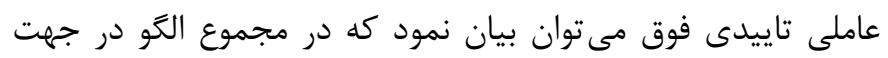

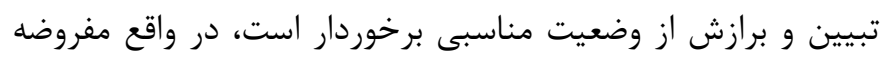

در ادامه جدول شاخصهاى روانسنجى سوالات آزمون يِ از اجرا در نمونه يزوهش كزارش شده است. نتايج ميانكين سؤالات در جدول r نشان مى دهد بيشترين ميانگين مربوط

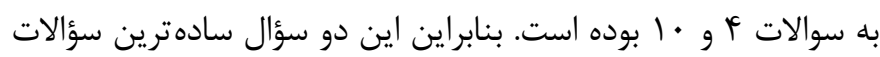

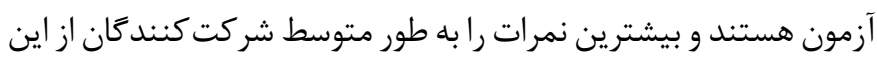

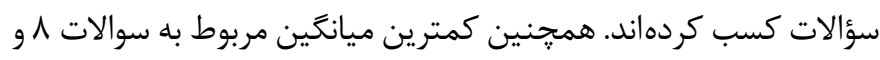

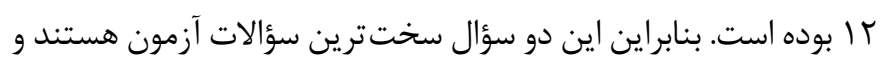
كمترين نمرات را به طور متوسط شركت كنند نمودهاند. نتايج حاصل از ضرايب تشخيص نيز نشان مى دهد سؤالات fأ،

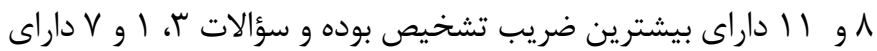


يزوهشكر مبنى بر ب عاملى بودن آزمون STMT مورد تأييد قراركرفت نفرى از شركت كنندكان استفاده شد. ضريب همبستكى بين اين دو مقياس در جدول ب كزارش شده است. با توجه به نتايج جدول . $(\mathrm{GFI}=\cdot / 9 \mathrm{~V}$ ، $\mathrm{RMSEA}=\cdot / \cdot \uparrow)$

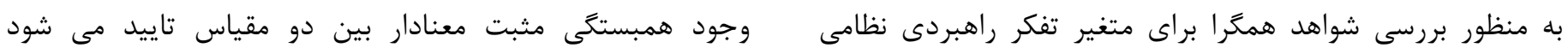
از يرسشنامه خود كزارش دهى تفكر راهبردى در يك نمونه ••

جدول r. شاخص هاى روان سنجى سوالات آزمون تفكر راهبردى نظامى

\begin{tabular}{|c|c|c|c|}
\hline انحراف استاندارد & ميانغين & ضريب تشخيص سؤال & كويه \\
\hline.$/ 9 V$ & . Mt & Tr/ & 1 \\
\hline $1 / \cdot r$ & 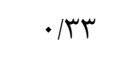 & $\cdot / 4 q$ & r \\
\hline$\cdot / 1 \Lambda$ &.$/ 99$ & $\cdot \pi \cdot$ & $r$ \\
\hline$\cdot / 19$ & $1 / 4$ & . $/ 4 T$ & f \\
\hline.$/ 99$ & $\cdot 1 \cdot 4$ & • & $\Delta$ \\
\hline$\cdot / 91$ & • $/ \Delta r$ & $\cdot \mid 9 \Delta$ & 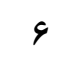 \\
\hline $1 / \cdot 1$ & $.1 \cdot 1$ & 酰 & v \\
\hline $1 / \cdot r$ & - & $\cdot \mid \Delta \Lambda$ & $\wedge$ \\
\hline $1 / \cdot 1$ & $\cdot 199$ & $\cdot / \Delta T$ & 9 \\
\hline.$/ 91$ & $1 / 14$ & . & 1. \\
\hline $1 / .9$ & $\cdot 1 \cdot 1$ & $\cdot / \Delta V$ & 11 \\
\hline $1 / 19$ & -.19 & $\cdot / 4 F$ & ir \\
\hline
\end{tabular}

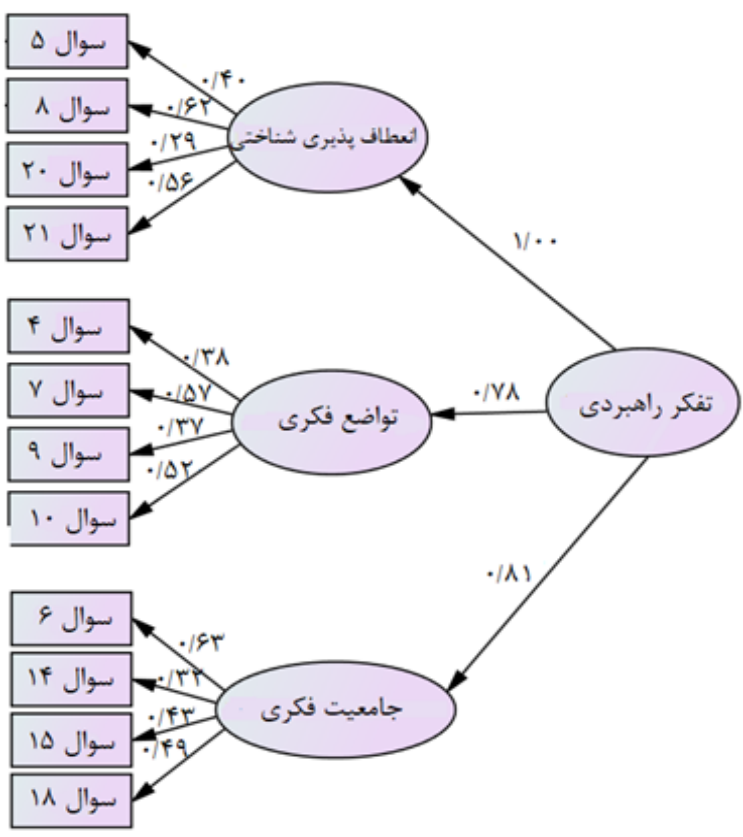

شكل 1 ـ مدل تحليل عاملى تأييدى در حالت ضرايب استاندارد شده 
جدول r. ضرايب همبستخى بين STMT با فرم خود كزارشدهى استاندارد تفكر راهبردى Goldman

\begin{tabular}{|c|c|c|}
\hline$r$ & 1 & مقياس \\
\hline & 1 & STMT-। \\
\hline 1 & $\cdot / \mu F$ & r-فرم خودَزارش \\
\hline
\end{tabular}

به منظور بررسى پايايى (Reliability) آزمون STMT ، روش همسانى به منظور استخراج نمرات هنجار ابعاد آزمون تفكر راهبردى مديران

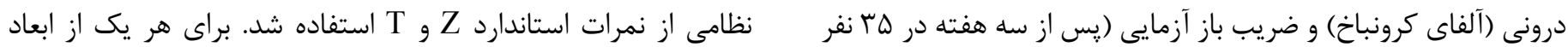

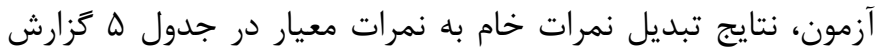
از تروه نمونه) به كار كرفته شد. همان كونه كه در جدول أ مشاهده مىشود ضرايب يايايى يرسشنامه در شده است. نتايج جدول ه نشان مى دهد نقطه برش در مقياس جامعيت فكرى و تواضع فكرى (ميانگَين) نمره خام ك است.

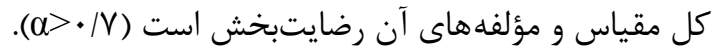

جدول Fأ. شاخص پايايى همسانى درونى كل مقياس STMT

\begin{tabular}{|c|c|c|}
\hline باز آزمايى & آلفاى كرونباخ & مقياس /یايايى \\
\hline$\cdot 1119$ & . IVYG & STMT (كل) STMT \\
\hline - MArF & $\cdot / V 9 \Delta$ & جامعيت فكرى \\
\hline - IAGF & ./V१। & تواضع فكرى \\
\hline$\cdot / \Lambda$ & $\cdot / V F$ & انعطاف يذيرى شناختى \\
\hline
\end{tabular}

جدول ه. هنجارسازى مقياس (نمرات Z و T)

\begin{tabular}{|c|c|c|c|c|c|c|}
\hline \multicolumn{2}{|c|}{ انعطاف يذيرى شناختى } & \multicolumn{2}{|c|}{ تواضع فكرى } & \multicolumn{2}{|c|}{ جامعيت فكرى } & \multirow{2}{*}{ نمر ه خام } \\
\hline $\mathbf{T}$ & $\mathbf{Z}$ & $\mathbf{T}$ & $\mathbf{Z}$ & $\mathbf{T}$ & $\mathbf{Z}$ & \\
\hline זr & $-1 / V I$ & $r I$ & $-r / 9 \mid$ & rI & $-r / \wedge 9$ & $-q$ \\
\hline rv & $-1 / T V$ & $r \omega$ & $-r / F \varphi$ & rq & $-r / \boldsymbol{Y}$. & r \\
\hline FT & $-\cdot / A T$ & rA & $-T / I V$ & $r$. & $-1 / 9 \Delta$ & $-r$ \\
\hline is & $-\cdot / \mu \Lambda$ & rس & $-1 / 9 V$ & ra & $-1 / \Delta 1$ & -1 \\
\hline 01 & .1 .9 & rᄉ & $-1 / 11$ & rq & $-1 / \cdot 9$ & . \\
\hline$\Delta \Delta$ & $\cdot|\Delta|$ & qr & -.199 & Fq & $-\cdot|9|$ & 1 \\
\hline c. &.$/ 90$ & is & $-\cdot / r$. & $4 q$ & $-\cdot / 1 r$ & $r$ \\
\hline$g F$ & $1 / 4$. & r & $\cdot / r \cdot$ & $\Delta r$ & $\cdot 1 / 19$ & r \\
\hline $9 \wedge$ & l/AF & $\Delta \Lambda$ & $\cdot / v 9$ & $\Delta V$ & $\cdot / V^{c}$ & f \\
\hline ve & $r / T V$ & r & $1 / T \Lambda$ & Gr & $1 / 11$ & $\Delta$ \\
\hline $\mathrm{V \Lambda}$ & T/VG & 91 & $1 / V \Lambda$ & 99 & $1 / 9 r$ & 4 \\
\hline$\Delta F$ & r/fr & $V f^{f}$ & $r / F \Delta$ & VI & $r / \cdot \Lambda$ & V \\
\hline
\end{tabular}


وضعيت مناسبى برخوردار است و مىتوان كَفت مفروضه يزوهشكر مبنى

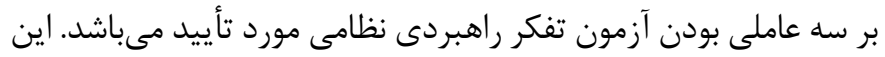
سه مؤلفه همانطور كه بِيشتر ذكر شد جامعيت فكرى، تواضع فكرى و

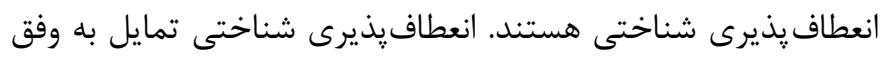

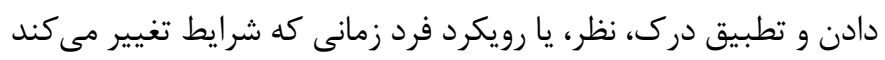
يا اطلاعات جديدى ارائه مىشود. جامعيت فكرى استقبال از اطلاعات و نظرات به دست آمده از طيف گستردهاى از منابع (افراد، گروهها، رشتههاى تحصيلى، يا ساير منابع مرتبط) است؛ و تواضع فكرى، سطح آرامش فكرى مرتبط با اشتباه كردن يا درك ناقص، همراه با تمايل به بررسى خود، بررسى مسائل، طورى كه اگر درى از مسائل به نحوى اشتباه باشد، جطور مىشود، است (YT). PJT Porterfield

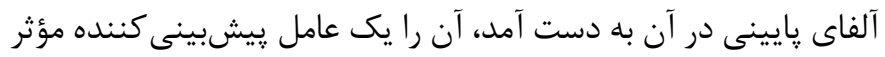

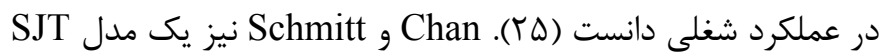
را در بخشى ديخر به كار كرفته و آلفاى نهايى صه| • را به دست آوردند (צץ). با اين وجود نمونههايى موفق از SJT هم قابل مشاهده است كه در آنها مقادير آلفا با قابليت اطمينان مناسب به دست آمده است (به آنائ

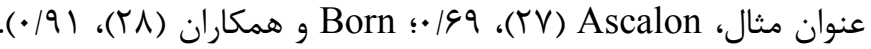
اين گونه بِيشنهاد شده كه تمركز بيشتر بر آزمون ساختارهاى معين به جاى دامنه كلى كار، مىتواند نتايج بهترى را حاصل كند (Y (Y).

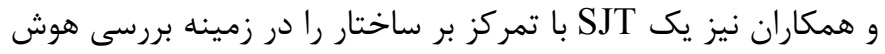

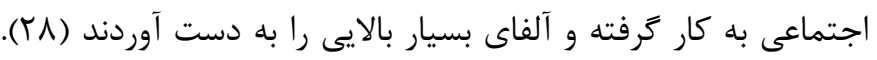

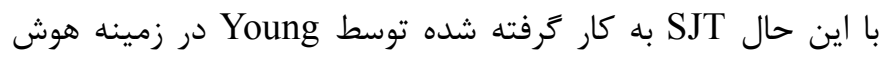

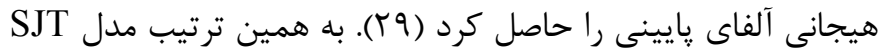
به كار گرفته شده توسط Smith با تمركز بر جهت كيرى كارآفرينى،

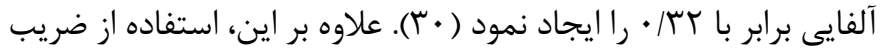
آلفا به عنوان شاخصى استاندارد براى گايايى و ثبات درونى، مورد باني

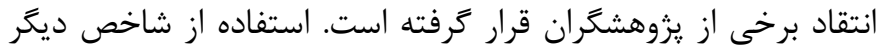
در ساختارهاى همكن، همانند يوشش محتواى يك دامنه نيز مىتواند

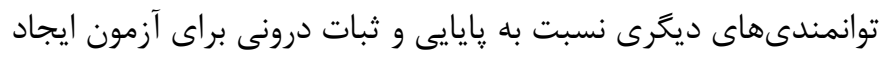

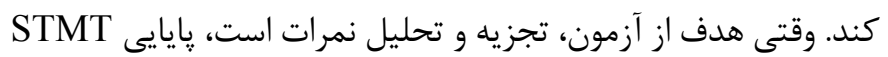

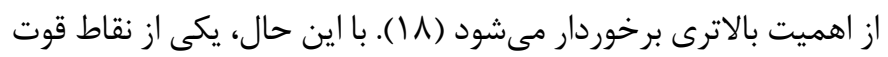
Sها، وفادارى به محتواست ( آب). نتيجه اين يزوهش نشان داد كه روايى همكرا اين آزمون در حد قابل قبولى است. ضريب همبستكى نمره كل مقياس با فرم خود ززارش دههى

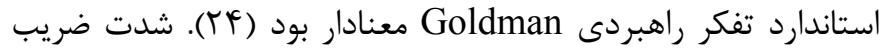

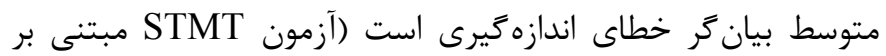

به دست آوردن درك جديد در مورد بهبود استراتزى سازمانى از طريق

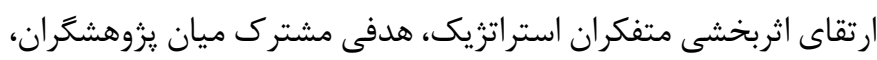

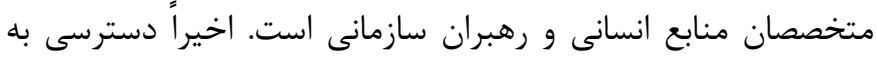
بخشهايى از سازمانها كه در آن تصميمات استراتزيك اخذ شده و از آن با عنوان جعبه سياه ياد مىشد، براى محققان ممكن شده است (T山). البته هنوز بايستى شناخت بيشترى نسبت به يويايى فردى و بين فردى درباره تفكر استراتزيكى و ايجاد استراتزى حاصل شود. يزوهش ئش حاضر در نظر داشت به منظور ارتقاى اين شناخت، يك ساختار جديد با عنوان ذهنيت تفكر استراتزيك را مفهومسازى كند. در كنار توانايى شناختى و دانش حاصله از حوزههاى مختلف كه به كمك زمان، تجربه

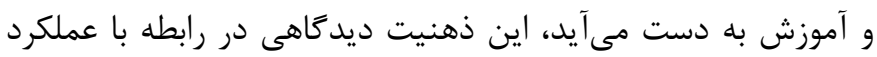

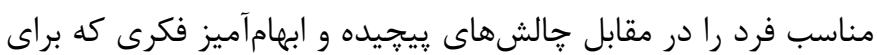
موفقيت استراتزيك مورد نياز است، ايجاد مى كند. در اين راستا هدف اصلى، ايجاد معيارى براى ارزيابى ذهنيت تفكر استراتزيك و كمك به شناسايى توانمندىهاى تفكر استراتزيك در ميان اعضاى سازمان و ارتقاى اين افراد تا سطح رهبرى استراتزيك بوده است. مطالعه حاضر در نظر داشت درك نظرى ذهنيت تفكر استراتزيك به عنوان يك ساختار و همجنين سنجش اين ساختار به كمك آزمون قضاوت

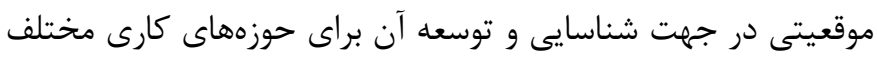

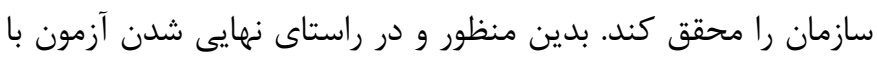

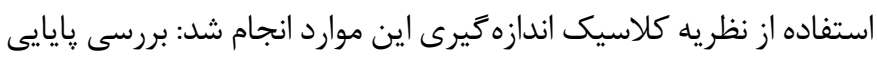
آزمون، بررسى روايى آزمون و استخراج نمرات هنجار. جهت بررسى روايى درايى

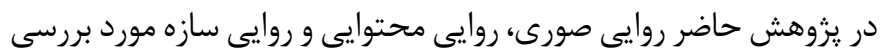
قرار گرفت. نتيجه اين يزوهش نشان داد كه در گام اول و بر اساس نظر متخصصان با تغييرات در r سوال، يرسشنامه جهت اجراى اوليه متشكل

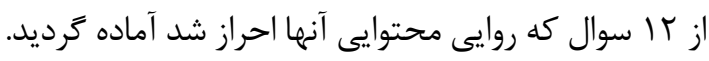

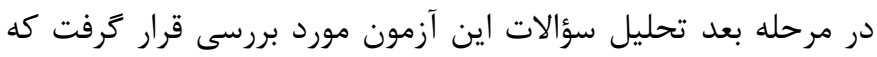

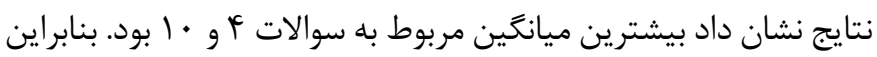

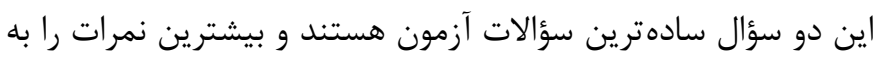

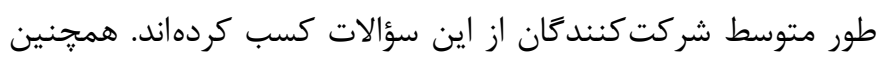

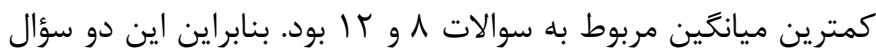
سخت ترين سؤالات آزمون هستند و كمترين نمرات را به طور متوسط شركت كنندًان از اين سؤالات كسب كردهاند. در مرحله بعد ساختار ب عاملى آزمون تفكر راهبردى نظامى با استفاده

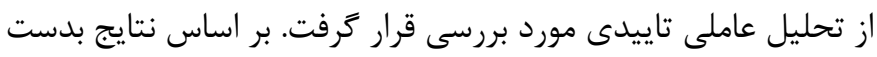

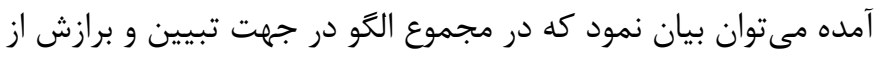


و بيشينهسازى امكان روانسنجى را به وجود آورد. با اين حال، به كارگيرى STMT داراى مشكلاتى همجون نبود ديدگاه كلى درباره الكوهاى فكر و تصميمَيرى در زندگى واقعى جوامعى است كه آزمون در آنها به انجام مىرسد. بر اساس موارد ذكر شده در باب آزمون تفكر راهبردى مديران نظامى، اين آزمون جديد در ارزشيابىهاى غربال گرى مىتواند اثرگذار باشد.

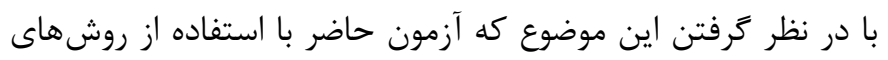
مناسب آمارى تهيه شده لذا بيشنهاد مىشود در كشور ما از اين ابزار غربال يزوهش مربوط به محيطهاى نظامى مى باشند، لذا درباره تعميم نتايج به ساير مشاغل بايد جانب احتياط رعايت شود.

\section{تشكر و قدرقاذى}

از كليه شركت كنند عالى دفاع ملى و تحقيقات راهبردى تشكر و قدردانى مى گردد. لازم به ذكر است اين يزوهش تحت نظر و با حمايت مالى دانشعاه عالى دفاع ملى و تحقيقات راهبردى صورت گرفته است.

\section{References}

1. Huber GP. Organizations: Theory, design, future. In Zedeck S, editor. APA handbook of industrial and organizational psychology. Vol 1. Building and developing the organization. Washington, DC:American Psychological Association;2011. pp. 117-60.

2. Huber GP. The necessary nature of future firms: Attributes of survivors in a changing world. California:Sage Publications;2003.

3. Stieglitz N, Knudsen T, Becker MC. Adaptation and inertia in dynamic environments. Strategic Management Journal. 2016;37(9):1854-1864.

4. Duhaime IM, Stimpert L, Chesley J. Strategic thinking: Today’s business imperative. New York:Routledge;2012.

5. Bethel SA, Prupas A, Ruby TZ, Smith MV. Change culture, reverse careerism. Washington, DC:National Defense University;2010.
محرك مبهمم و توانايى تصميم گيرى است، فرم خود گزارش دهى مبتنى بر زَارش شخصى و ذهنى افراد است). علاوه بر اين، شايان ذكر است تفاوتهاى روششناختى ميان STMT و آزمون Goldman مى تواند بر تفاوت نمرات تأثير گذار باشد. آزمون Goldman عمدتاً بر خود ارزيابى رئ مخاطب و كرايشهاى كلى او متكى است، اما STMT ياسخدهنده را راس در شرايطى قرار مىدهد كه اين گرايشها را در قضاوتهاى موقعيتى متعدد به كار بخيرد.

\section{نتيجهَ كَرى}

انتخاب آزمون قضاوت وضعيتى به عنوان روشى براى ارزيابى ذهنيت تفكر استراتزيك، از جمله نقاط قوت يزوهش حاضر است. نكته مههم اينكه فرمت SJT روشى نسبتاً ارزان محسوب شده و امكان شبيهسازى آر آن در مقياس كوجى وجود دارد، بدون آنكه بر خودآكاهى و صداقت ياسخدهندكان اتكا شود. از جمله مزاياى ديكر اين روش، اعتبار، ״ييامدهاى نامطلوب كمتر و همجنين امكان مباحثات زروهى و خود ارتقايى براى افراد خواهد بود. استفاده از نمونههاى بزركتر مىتواند جمعآورى دادهها را تسهيل كرده و همجنين انعطافيذيرى بالاتر

6. Graetz F. Strategic thinking versus strategic planning: To wards understanding the complementarities. Management Decision. 2002;40(2):456-462.

7. Liedtka JM. Strategic thinking: Can it be taught?. Long Range Planning. 1998;31(1):120-129.

8. Eifler BS. Developing strategic thinking leaders in the US Army [Research Project]. Carlisle Barracks Pennsylvania:U.S. Army War College;2011.

9. Moldoveanu M. Thinking strategically about thinking strategically: The computational structure and dynamics of managerial problem selection and formulation. Strategic Management Journal. 2009;30(7):737-763.

10. Dragoni L, Oh IS, Vankatwyk P, Tesluk PE. Developing executive leaders: The relative contribution of cognitive ability, personality, and the accumulation of work experience in predicting strategic thinking competency. Personnel Psychology. 
2011;64(4):829-864.

11. Alberts DS, Hayes RE. Power to the edge: Command... control... in the information age. Office of the Assistant Secretary of Defense Washington DC Command and Control Research Program (CCRP);2003.

12. Wolters HM, Grome AP, Hinds RM. Exploring strategic thinking: Insights to assess, develop, and retain strategic thinkers [Research Project]. Fairborn, Ohio:United States Army Research Institute for the Behavioral and Social Sciences;2013.

13. Sackett AL, Karrasch AI, Weyhrauch W, Goldman EF. Enhancing the strategic capability of the army: An investigation of strategic thinking tasks, skills, and development. Fort Belvoir, Virginia:Army Research Inst for the Behavioral and Social Sciences;2016.

14. Grier RA. Military cognitive readiness at the operational and strategic levels: A theoretical model for measurement development. Journal of Cognitive Engineering and Decision Making. 2012;6(4):358-392.

15. Pisapia J, Reyes-Guerra D, Coukos-Semmel E. Developing the leader's strategic mindset: Establishing the measures. Leadership Review. 2005;5(1):41-68.

16. Yorks L, Nicolaides A. A conceptual model for developing mindsets for strategic insight under conditions of complexity and high uncertainty. Human Resource Development Review. 2012;11(2):182-202.

17. Moss F. Preliminary report of a study of social intelligence and executive ability. Public Personnel Studies. 1931;9:2-9.

18. Schmidt FL, Hunter JE. The validity and utility of selection methods in personnel psychology: Practical and theoretical implications of 85 years of research findings. Psychological Bulletin. 1998;124(2):262-274.

19. Arthur Jr W, Villado AJ. The importance of distinguishing between constructs and methods when comparing predictors in personnel selection research and practice. Journal of Applied Psychology. 2008;93(2):435-442.

20. Pisapia J, Pang NS, Hee TF, Lin Y, Morris JD. A comparison of the use of strategic thinking skills of aspiring school leaders in Hong Kong, Malaysia, Shanghai, and the United States: An exploratory study. International Education Studies. 2009;2(2):46-58.

21. Hausknecht JP, Day DV, Thomas SC. Applicant reactions to selection procedures: An updated model and meta analysis. Personnel Psychology. 2004;57(3):639-683.

22. Weyhrauch WS. Development and preliminary validation of the Strategic Thinking Mindset Test (STMT). Washington DC:Consortium of Universities Washington DC;2017.

23. Tabakhnick BG, Fidell LS. Using multivariate statistics. 5th ed. Boston:Allyn \& Bocon;2007.

24. Goldman EF. Strategic thinking at the top. MIT Sloan Management Review. 2007;48(4):75-81.

25. Porterfield, R. W. The development, psychometric evaluation, and validation of a situational judgment inventory for security officers [Doctoral Dissertation]. Arlington:The University of Texas;2001.

26. Chan D, Schmitt N. Video-based versus paper-and-pencil method of assessment in situational judgment tests: Subgroup differences in test performance and face validity perceptions. Journal of Applied Psychology. 2007;82(1):143-159.

27. Ascalon ME. Improving expatriate selection: Development of a situational judgment test to measure cross-cultural social intelligence [Doctoral Dissertation]. Tulsa, Oklahoma:The University of Tulsa;2004.

28. Born MP, Van Der Maesen De Sombreff PE, Van Der Zee KI. A multimedia situational judgment test for social intelligence. Journal of eCommerce and Psychology. 2001;2(2):54-72. 29. Young RE. The creation of an emotional intelligence situational judgment test with the ability-based model of emotional intelligence as the operative construct [Doctoral Dissertation]. San Diego:Alliant International University;2004.

30. Smith MR. Initial development and validation of the entrepreneurial orientation profile inventory (EOPI) [Doctoral Dissertation]. Manhattan:Kansas State University;2011.

31. Weekley JA, Ployhart RE. An introduction to situational judgment tests. In Weekley JA, Ployhart RE, editors. Situational judgment tests: 